\title{
Internal Transcribed Spacer Sequence-Based Phylogeny and Polymerase Chain Reaction-Restriction Fragment Length Polymorphism Differentiation of Tilletia walkeri and T. indica
}

\author{
Laurene Levy, Lisa A. Castlebury, Lori M. Carris, Robert J. Meyer, and Guillermo Pimentel
}

First and fourth authors: USDA-APHIS PPQ National Plant Germplasm Quarantine Center, Beltsville, MD 20705; second author: USDAARS Systematic Botany and Mycology Laboratory, Beltsville, MD 20705; and third and fifth authors: Department of Plant Pathology, Washington State University, Pullman 99164.

Accepted for publication 1 June 2001.

\begin{abstract}
Levy, L., Castlebury, L. A., Carris, L. M., Meyer, R. J., and Pimentel, G. 2001. Internal transcribed spacer sequence-based phylogeny and polymerase chain reaction-restriction fragment length polymorphism differentiation of Tilletia walkeri and T. indica. Phytopathology 91:935940.

A polymerase chain reaction-restriction fragment length polymorphism assay to distinguish Tilleita walkeri, a rye grass bunt fungus that occurs in the southeastern United States and Oregon, from $T$. indica, the Karnal

bunt fungus, is described. The internal transcribed spacer (ITS) region of the ribosomal DNA repeat unit was amplified and sequenced for isolates of T. indica, T. walkeri, T. horrida, and a number of other taxa in the genus Tilletia. A unique restriction digest site in the ITS1 region of $T$. walkeri was identified that distinguishes it from the other taxa in the genus. Phylogenetic analysis of the taxa based on ITS sequence data revealed a close relationship between $T$. indica and T. walkeri, but more distant relationships between these two species and other morphologically similar taxa.
\end{abstract}

Tilletia indica Mitra, the causal agent of Karnal bunt of wheat, was first described on wheat near Karnal, India in 1931 (16,17). T. indica, a floret-infecting fungus, causes a partial bunt of wheat seeds and infected seeds have a trimethylamine odor $(12,17)$. Since its discovery, it has been reported from Pakistan, Nepal, Afghanistan, Mexico, and the United States. $(2,26)$. This fungus is the target of international quarantines by most wheat-growing nations and its presence poses serious risks to the ability of a country to export its wheat. Following the discovery of T. indica in the southwestern United States in 1996 (26), the Animal and Plant Health Inspection Service (APHIS) of the United States Department of Agriculture (USDA) initiated the National Karnal Bunt Survey to determine the extent of this outbreak in the United States. Survey samples were sent to the USDA-APHIS National Plant Germplasm Quarantine Laboratory at Beltsville, MD, for polymerase chain reaction (PCR)-based identification using the method of Smith et al. (21), and to the APHIS National Mycologist and the USDA-Agricultural Research Service (ARS) Systematic Botany and Mycology Laboratory for morphological identification.

At that time, the most morphologically similar species of Tilletia known to occur in the United States and the most likely to be found in grain handling systems was T. horrida Takah. (T. barclayana (Bref.) Sacc. \& Syd. in Sacc.). T. horrida, the rice (Oryza sativa L.) kernel smut fungus, produces dark-brown tuberculate teliospores similar to those of $T$. indica, although teliospores of $T$. horrida are, on average, smaller (6). Wheat samples from the southern United States may be contaminated with $T$. horrida due to the common practice of grain processors handling both wheat and rice. To distinguish $T$. indica from $T$. horrida, a

Corresponding author: L. A. Castlebury; E-mail address: lisa@nt.ars-grin.gov

Publication no. P-2001-0726-01R

This article is in the public domain and not copyrightable. It may be freely reprinted with customary crediting of the source. The American Phytopathological Society, 2001.
PCR test was developed (21). This test was based on PCR primers that amplified a $T$. indica-specific mitochondrial DNA fragment and did not amplify products from $T$. horrida DNA. Primers specific for the internal transcribed spacer (ITS) 2 region of the nuclear ribosomal DNA (rDNA) repeat unit were used as positive controls (24).

Until November 1996, results from the National Karnal Bunt Survey based on the PCR assay indicated that the T. indica outbreak was confined to the southwestern United States. However, in late 1996 and early 1997, teliospores from survey samples of pasture seed mixtures originating from Oregon tested positive for $T$. indica. Eventually, these teliospores were traced to bunted annual rye grass seeds (Lolium multiflorum L.) (2). Morphologically similar teliospores also were found in wheat seed washes from the southeastern United States, but bunted wheat seeds were never found in survey samples from Oregon or the southeastern United States $(2,6,8)$. Mycologists with APHIS and ARS observed morphological differences between $T$. indica and this previously unknown Tilletia sp. on rye grass, which was eventually described as T. walkeri Castlebury \& Carris (6).

During the course of the National Karnal Bunt Survey, fragment length variation was observed in the ITS positive controls of the various taxa tested with the PCR assay of Smith et al. (21). Fungal rDNA has been previously found to contain regions of variability within genera $(20,24)$. Recent studies using restriction fragment length polymorphism (RFLP) of the ITS region have identified taxon-specific markers among the common and dwarf wheat bunts and related taxa $(3-5,18)$. In this study, we amplified and sequenced the ITS1 and ITS2 regions of the rDNA, including the 5.8S rDNA, from isolates of T. walkeri, T. indica, T. horrida, and other taxa in the genus Tilletia. Our specific objective was to exploit any sequence variation to differentiate $T$. walkeri from $T$. indica and possibly other taxa in the genus Tilletia, and to determine which taxa were most closely related to $T$. indica in order to better select the most appropriate taxa for testing identification methods both now and in the future. 


\section{MATERIALS AND METHODS}

Spore germination, culture conditions, and DNA isolation. Strains of Tilletia used in this study are listed in Table 1. All cultures used in this study were single teliospore or monobasidiospore lines from bunted seeds or seed washes. Teliospores removed from bunted wheat kernels were soaked in $5 \mathrm{ml}$ of distilled water or Tween-water (1 to 2 drops of Tween 20 in $100 \mathrm{ml}$ of distilled water) for $\approx 24 \mathrm{~h}$ at 22 to $25^{\circ} \mathrm{C}$. Teliospores were pelleted by centrifugation at $\approx 1,000 \times g$ in an IEC CL centrifuge for $3 \mathrm{~min}$. The supernatant was discarded and the pellet was resuspended in $10 \mathrm{ml}$ of $0.42 \% \mathrm{NaClO}(8 \% \mathrm{vol} / \mathrm{vol}$ commercial bleach) and immediately centrifuged as described above for $1 \mathrm{~min}$. The supernatant was discarded and the pellet washed twice with $14 \mathrm{ml}$ of sterile water followed by a 1-min centrifugation as above. Telio- spores were resuspended in $1.8 \mathrm{ml}$ of sterile water, which was divided in half and spread on water agar (WA) supplemented with streptomycin and ampicillin at $100 \mathrm{mg} /$ liter each and incubated at $19^{\circ} \mathrm{C}$. Small blocks of agar with individual germinating teliospores were aseptically removed with a scalpel and affixed to the lid of a petri dish containing potato dextrose broth so that secondary basidiospores were discharged into the broth. After 7 to 14 days, mycelia were removed from the dish, blotted on filter paper, vacuum-dried in 1.5- $\mathrm{ml}$ microcentrifuge tubes, and stored at $-20^{\circ} \mathrm{C}$.

To extract DNA, vacuum-dried mycelium was frozen in liquid nitrogen and pulverized with a microtube pestle. Genomic DNA was isolated using the PureGene DNA isolation kit (Gentra Systems, Inc., Research Triangle, NC) according to the manufacturer's instructions.

TABLE 1. Geographic origin and host of Tilletia isolates used in the study, and results from ScaI restriction digest of the internal transcribed spacer 1 (ITS1) region of the ribosomal DNA

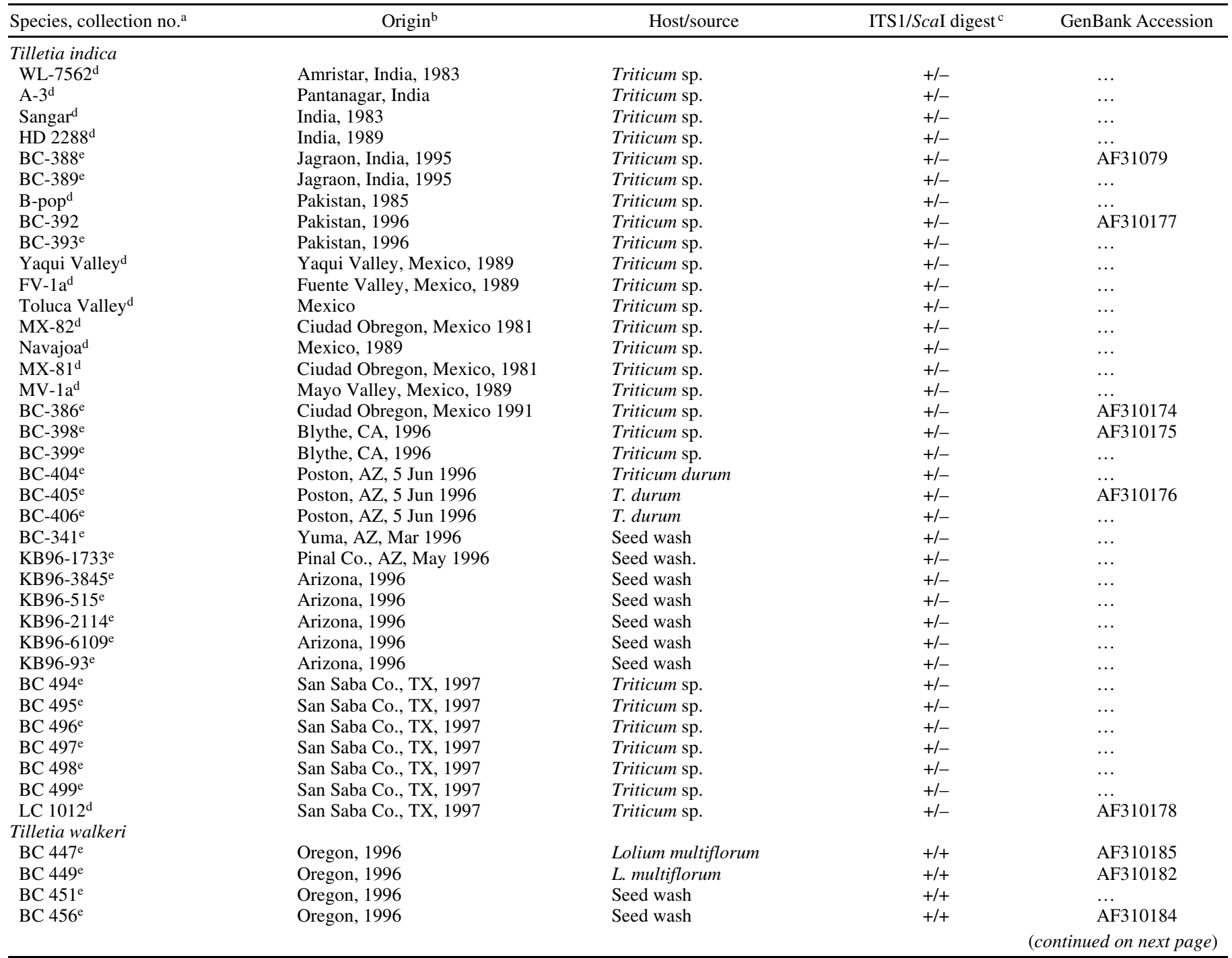

$\bar{a}$ Culture numbers are in parentheses. The presence of a city, town, or country name in the collection number does not necessarily indicate the presence of the fungus in that location.

${ }^{\mathrm{b}}$ Geographic origin and sample collection date.

${ }^{\mathrm{c}}$ ITS1 = polymerase chain reaction $(\mathrm{PCR})$ amplification of ITS1 region DNA; + indicates amplification of a DNA band with primers ITS5 and ITS2. ScaI = restriction fragment length polymorphism analysis of the ITS1 PCR product with $S c a$ I; + indicates digestion of the ITS1 PCR product into two bands of approximately 140 and 160 bp in size; - indicates the ITS1 PCR product was not digested with ScaI.

d Samples provided as purified DNA from G. Peterson, USDA-ARS-FDWSRU.

e Samples provided as freeze-dried mycelium from R. Meyer, USDA-APHIS-NPGQC.

${ }^{\mathrm{f}}$ Sample provided as bunted seed by M. Palm, USDA-APHIS.

g Sample provided as bunted seed by B. Cunfer, University of Georgia.

h Samples provided as freeze-dried mycelium from L. Carris, Washington State University.

i Sample provided as dry teliospores from P. Paulech, Slovak Academy of Science. 
PCR and gel analysis. Purified DNA was diluted 1:10 with sterile water, and $1 \mu \mathrm{l}$ was used in amplification reactions containing $T$. indica-specific primer pairs Ti17 M1/M2 and Ti57 M1/M2 (21). The ITS1 region was amplified using primer pair ITS5/2 as a positive control (24). These primers amplify a small portion of the small subunit rDNA, the ITS1 region, and the $5^{\prime}$ end of the 5.8S rDNA. Fungal DNA was amplified in 50- $\mu$ l reactions using a DNA amplification kit (Perkin-Elmer, Applied Biosystems, Foster City, CA) containing $10 \mathrm{mM}$ Tris- $\mathrm{HCl}$ $(\mathrm{pH} 8.3), 50 \mathrm{mM} \mathrm{KCl}, 1.5 \mathrm{mM} \mathrm{MgCl}_{2}$, gelatin at $10 \mu \mathrm{g} / \mathrm{ml}$, $200 \mu \mathrm{M}$ each dNTP, $20 \mathrm{pmol}$ each primer, and 1.25 units of AmpliTaq. The thermal cycler program was as follows: 1 denaturation cycle of $94^{\circ} \mathrm{C}$ for $3 \mathrm{~min}, 30$ cycles of $94^{\circ} \mathrm{C}$ for $1 \mathrm{~min}$, $60^{\circ} \mathrm{C}$ for $1 \mathrm{~min}$, and $72^{\circ} \mathrm{C}$ for $2 \mathrm{~min}$, followed by a final extension step at $72^{\circ} \mathrm{C}$ for $10 \mathrm{~min}$. PCR products were electrophoresed in $5 \%$ polyacrylamide in $1 \times \mathrm{TBE}(89 \mathrm{mM}$ Tris, $89 \mathrm{mM}$ borate, and
$2.5 \mathrm{mM}$ EDTA) at $110 \mathrm{~V}$ for $2 \mathrm{~h}$ and visualized with silver nitrate. PCR products for sequencing were amplified under the same conditions as described above using the primer pairs ITS5/4 for the complete ITS region or ITS5/2 and ITS3/4 to amplify the region in two parts (24).

ITS PCR product purification, DNA sequencing, and analysis. PCR products were separated in 1.2\% agarose electrophoresed in $1 \times$ TAE buffer (40 mM Tris-acetate, [pH 8.0], $1 \mathrm{mM}$ EDTA) at $70 \mathrm{~V}$ for $1.2 \mathrm{~h}$ followed by staining with ethidium bromide. Bands were excised, crushed, and incubated overnight at $35^{\circ} \mathrm{C}$ with elution buffer (20 mM Tris- $\mathrm{HCl}, \mathrm{pH} 8.0,1 \mathrm{mM}$ EDTA) (14) at $400 \mu \mathrm{l}$ per tube. Eluted DNA was filtered through $0.45-\mu \mathrm{M}$ Spin-X columns (CoStar), precipitated, and concentrated by centrifugation. PCR products were further purified using the Wizard PCR Preps DNA purification kit according to the manufacturer's recommendations (Promega, Madison, WI).

TABLE 1. (continued from preceding page)

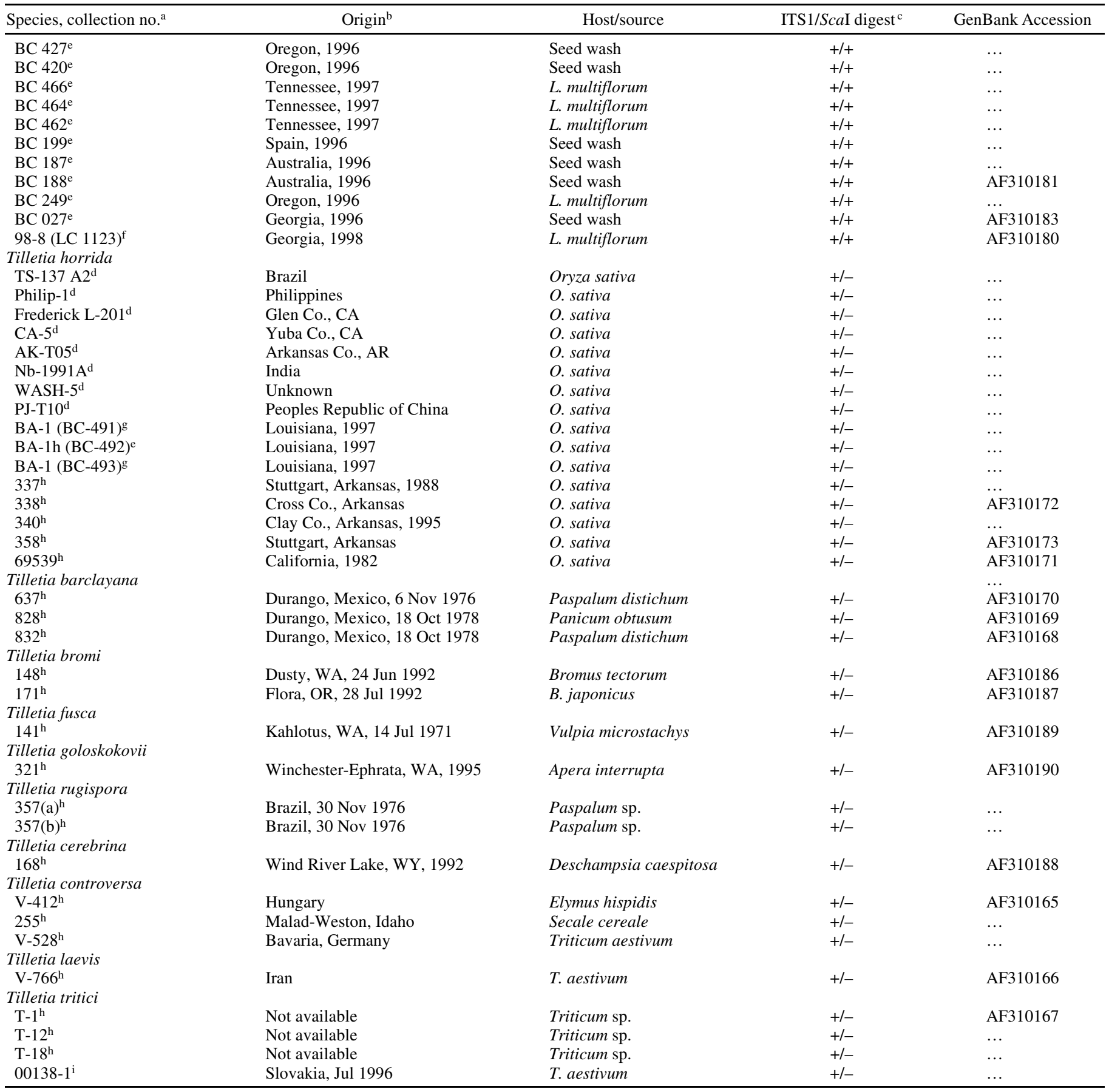


Purified PCR products were sequenced in both directions using dye-terminator sequencing with an ABI 373A automated sequencing system at the DNA Sequencing Facility at the University of Maryland (College Park, MD) and an ABI 310 (Applied Biosystems) at the USDA Systematic Botany and Mycology Lab. The Lasergene software package (DNASTAR, Madison, WI) was used for processing and editing raw sequence data using the EditSeq function. The MapDraw feature of DNAStar was used to generate a list of restriction enzymes based on the sequences for the isolates sequenced.

Enzymatic digestion of ITS PCR products. ITS1 PCR products were digested directly with the restriction enzyme ScaI (Gibco BRL Corp., Gaithersburg, MD) using $3 \mu \mathrm{l}$ of PCR product, $1.2 \mu \mathrm{l}$ of buffer (10X), and $7.8 \mu \mathrm{l}$ of sterile $\mathrm{H}_{2} \mathrm{O}$ at $37^{\circ} \mathrm{C}$ for 2 to $4 \mathrm{~h}$. Enzymatic digests were size fractionated in polyacrylamide and visualized with silver nitrate. PCR products $(10 \mu \mathrm{l})$ amplified with ITS5/4 (ITS1, 5.8S rDNA, and ITS2 regions) were also digested with $S c a$ I for 1 to $2 \mathrm{~h}$, electrophoresed in 3\% NuSieve 3:1 (FMC BioProducts, Rockland, ME) agarose at $100 \mathrm{~V}$ for $2 \mathrm{~h}$, and visualized with ethidium bromide under UV light.

Phylogenetic analysis of ITS sequences. Sequences were manually aligned using GeneDoc (distributed by K. Nicholas). Phylogenetic analysis using parsimony (PAUP; version 4.08b, Sinnauer, Sunderland, MA) was used to determine relationships of the taxa sequenced with the following settings: heuristic search option with random addition of sequences (10 replicates), tree-bisection-reconnection branch swapping, and steepest descent. Only

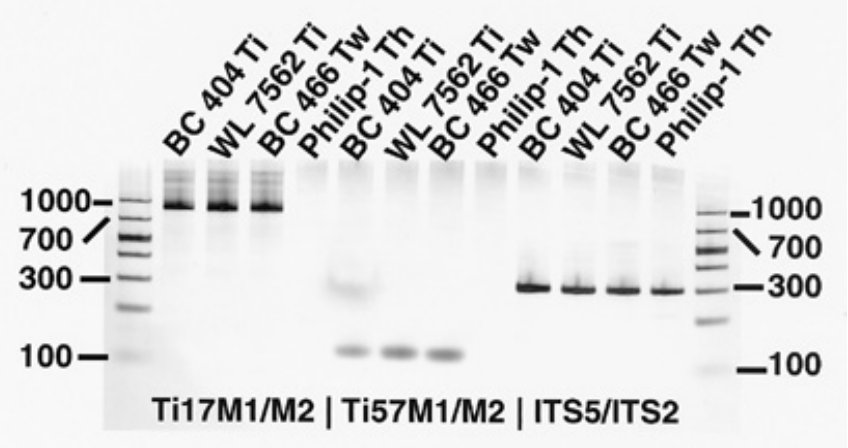

Fig. 1. Tilletia indica-specific polymerase chain reaction (PCR) assay of Smith et al. (21) showing PCR amplification from $T$. indica and T. walkeri but not $T$. horrida with the $T$. indica-specific primers and for all taxa with internal transcribed spacer region positive controls. Lanes 1 and 14, 100-bp marker; lanes 2, 3, 6, 7, 10, and 11, T. indica; lanes 4, 8, and 12, T. walkeri; and lanes 5, 9, and 13, T. horrida.

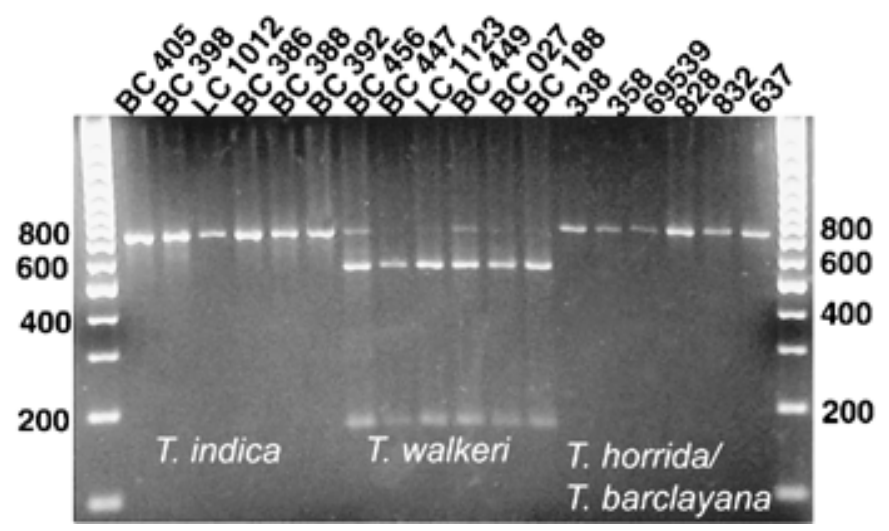

Fig. 2. Agarose gel electrophoresis of ScaI restriction enzyme digest of internal transcribe spacer 1 (ITS1), 5.8S, and ITS2 ribosomal DNA polymerase chain reaction products for morphologically similar taxa in the genus Tilletia. Lanes 1 and 20, 100-bp ladder; lanes 2 to 7, T. indica; lanes 8 to 13, T. walkeri; lanes 14 to 16 , T. horrida; and lanes 17 to 19 , T. barclayana. parsimony informative characters were included in the analysis and were treated as unordered with equal weights. Gaps were treated as missing data. One thousand bootstrap replicates were performed to estimate the relative support for the branches. Trees were midpoint rooted due to the unavailability of a true outgroup sequence.

\section{RESULTS}

PCR assays and restriction enzyme digestion. The PCR assay using the $T$. indica-specific primer pairs Ti17 M1/M2 and Ti57 M1/M2 amplified products of similar size from both $T$. indica and $T$. walkeri, but did not amplify products from $T$. horrida DNA (Fig. 1). Sequence analysis of the entire ITS region identified a $S c a$ I restriction enzyme site in the ITS1 region of $T$. walkeri that was not present in T. indica or other Tilletia spp. included in the study. The ITS ScaI RFLP-PCR test (ScaI test) has been screened against 36 isolates of $T$. indica, 15 isolates of $T$. walkeri, and 34 isolates of taxa in the genus Tilletia from wheat and other grasses (Fig. 2; Table 1). Sequences deposited in GenBank are listed in Table 1.

Sequence analysis. Among the 12 isolates of $T$. indica and $T$. walkeri sequenced, $T$. walkeri differed from $T$. indica at two positions, one of which was a part of the ScaI site. Both sites were $\mathrm{A} / \mathrm{G}$ transitions located in the ITS1 region and did not vary between isolates of the two taxa. In addition, among $T$. indica isolates, LC 1012 differed from the other isolates at one position (C/A transversion), isolate BC 386 differed from the other isolates at one position (G/A transition), and isolate BC 398 also differed from the others by a $\mathrm{G}$ to A transition. Among T. walkeri isolates, BC 447 differed from all other T. walkeri and T. indica isolates by one substitution (G/A transition). All of these substitutions were located in the ITS2 region.

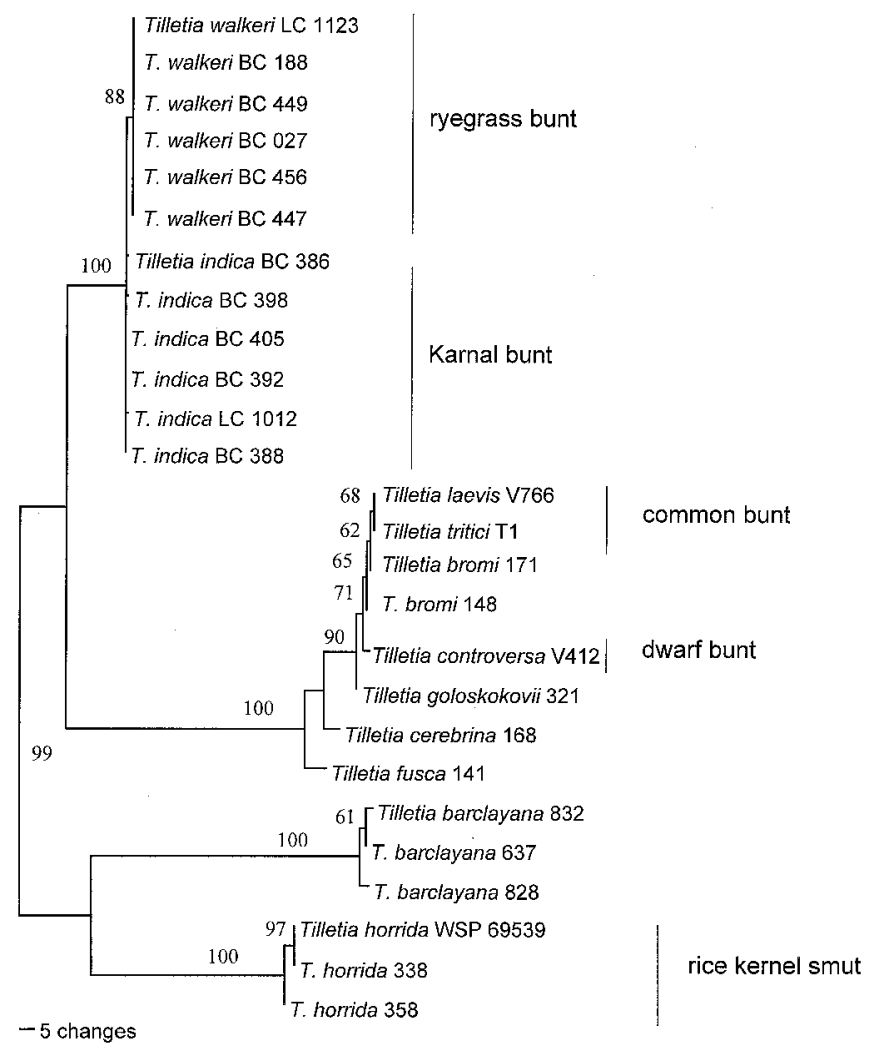

Fig. 3. One of four most parsimonious trees showing internal transcribed spacer 1 (ITS1), 5.8S, and ITS2 ribosomal DNA phylogeny of taxa in the genus Tilletia. Consistency index $=0.902$, retention index $=0.974$, rescaled consistency index $=0.879$. Bootstrap values greater than $50 \%$ are shown above the branches. 
T. tritici (Bjerk.) G. Wint. in Rabenh. and T. laevis Kühn in Rabenh. differed by one insertion/deletion (indel) and T. controversa Kühn in Rabenh. differed from T. tritici and T. laevis at five positions (excluding the indel site difference between $T$. tritici and $T$. laevis. Sequences of T. barclayana and T. horrida, previously synonymized taxa (22), were highly diverged and difficult to align. Within T. barclayana, isolate 828 differed from isolates 832 and 637 by five substitutions and one indel, isolate 832 differed from 828 and 637 by two substitutions, and isolate 637 differed from 828 and 832 by two substitutions. Within T. horrida, isolate 338 differed from isolates 358 and 69539 by one substitution and isolate 358 differed from 338 and WSP 69539 by three substitutions.

The alignment consisted of 697 total characters, of which 219 were parsimony informative and was submitted to TreeBase (S618). Phylogenetic analysis resulted in four most-parsimonious trees 327 steps long (consistency index $=0.902$, retention index $=$ 0.974 , rescaled consistency index $=0.879$ ) differing only in the arrangement of taxa within terminal groups and showed $T$. indica and T. walkeri to be more closely related to each other than to other taxa included in the analysis (Fig. 3). T. horrida, previously assumed to be closely related to $T$. indica based on similar teliospore morphology and synonymous with $T$. barclayana, is quite distant from $T$. indica and T. walkeri as well as from T. barclayana from Panicum and Paspalum. The common and dwarf bunt fungi clustered most closely with isolates from the T. fusca Ellis \& Everh. (T. bromi (Brockm.) Brockm.) complex with relatively short branch lengths indicating the small amounts of sequence variation among these fungi.

\section{DISCUSSION}

DNA sequencing and restriction digest results show that $T$. walkeri can be easily distinguished from $T$. indica and other morphologically similar bunt fungi with a $S c a$ I restriction digest of either the ITS 1 region alone or the entire ITS1, 5.8S, and ITS2 region of the nuclear rDNA repeat unit. Although T. walkeri, T. indica, and T. horrida can all be distinguished using morphological characters, identifications based on a single or a few teliospores can be problematic due to the intergradation of morphological characters (6). In many areas, rye grass may be growing alongside or within fields of wheat and accurate identifications are extremely important $(2,6,8)$. Quarantine agencies require unequivocal decisions regarding the identities of quarantine pests and morphologically similar nonquarantine pests when millions of dollars of imports and exports are at stake.

Recently, species-specific PCR primers and a TaqMan test for both $T$. indica and $T$. walkeri have been developed (11) based on the mitochondrial DNA fragment that was the basis of the Smith et al. (21) PCR-based T. indica identification method. These species-specific PCR primers provide a presence/absence test for fragments specific to each of the two species. In such presence/ absence diagnostic assays, it is necessary to include a positive control reaction so that negative results can be properly attributed to the absence of the primer annealing sites rather than a failure of the DNA to amplify due to degradation of the DNA, PCR inhibitors, or reagent problems. Previously mentioned PCR identification methods used the ITS3/IT4 primer set, which amplifies the ITS2 region and part of the 5.8S rDNA (21), and the primer set ITS5/2, which amplifies the ITS1 region and part of the $5.8 \mathrm{~S}$ rDNA (11), as positive controls. The $S c a$ I test, using PCR primer set ITS5/2 or ITS5/4, can be used alone to provide molecular identification of $T$. walkeri or in conjunction with either of the published PCR-based identification systems to provide independent confirmation of results.

The methods of Smith et al. (21), Frederick et al. (11), and this method all essentially require that single spores be isolated either for germination or for direct PCR on individual spores. Although spores can be collected from seed washes or swabs of grainholding facilities, for maximum accuracy none of these PCRbased tests should be used on samples potentially containing a mixture of species. The ITS primers used in this method will amplify from nearly all fungal DNA, as well as from other eukaryotic DNA, so it is critical that spores first be examined morphologically to confirm that the fungus is a species of Tilletia. Currently, approximately 5 to 7 days are required for the germination of teliospores $(6,13)$ and an additional 5 to 7 days for the production of enough mycelium for DNA extraction. McDonald et al. (15) reported direct amplification of DNA from species of Tilletia using the ITS3/4 primer set (24) as well as the Ti17 M1/M2 primers (21). Bonde et al. (1) reported the use of acidic electrolyzed water to enhance the germination of teliospores. Use of the above-mentioned methods in conjunction with the ScaI-ITS 1 restriction digest and other methods could reduce this time at least by half.

Sequence analysis showed relatively few differences in the ITS region among isolates of $T$. indica and $T$. walkeri. Similarly, there were few differences in the ITS region among isolates of closely related yet distinct taxa in the dwarf and common wheat bunt clade. At the same time, similar amounts of variation were shown among the $T$. horrida isolates and the $T$. barclayana isolates from Mexico, although sequences from these two taxa were highly diverged from each other and do not support their synonymy as reported by Tullis and Johnson (22). Whitney (25) had previously questioned the synonymy of $T$. horrida and $T$. barclayana based on host inoculation experiments and Royer and Rytter (19) were unable to artificially infect Pennisetum clandestinum Hochst. Ex Chiov. with T. horrida (as T. barclayana).

Although bootstrap values for the terminal clades are high, relationships of these clades to one another cannot truly be resolved due to the large amount of sequence variation between terminal clades, which resulted in some difficulty in aligning these sequences, the relatively small number of taxa included, and the lack of a true outgroup taxon. These data suggest that the rates of change in this region of the rDNA may vary widely across the genus and that ITS sequence analysis is not appropriate for determining broader relationships among these fungi. To date, there have been no published molecular phylogenetic studies of taxa within the genus Tilletia and the low level of variation in the ITS regions between closely related species in this study indicates that other gene sequences will be required to determine phylogenetic species and generic limits. Some authorities have considered the tuberculate-spored bunts to belong in a separate genus, Neovossia (23), while others have retained them in Tilletia $(9,10)$. In addition to teliospore ornamentation, the tuberculate- and reticulate-spored bunt species differ in the time and location of dikaryon formation and host infection. The phylogenetic analysis based on ITS sequences shows that the reticulate-spored Tilletia spp. and the smooth-spored T. laevis form a single clade, whereas the tuberculate-spored taxa were in two strongly supported clades.

Although the results of this study indicate that the reticulatespored Tilletia spp. included in this study are closely related, it fails to support the tuberculate-spored taxa as a monophyletic group. Additionally, phylogenetic analysis of the nuclear rDNA large subunit for these species has failed to support the monophyly of the tuberculate-spored species (7). The results of this study also point out the necessity of working with more than one isolate of different species in this genus for both molecular systematics and diagnostics. A better understanding of the taxonomic limits among these groups of bunt fungi is important for selecting the most appropriate taxa to test the specificity of diagnostic procedures.

\section{ACKNOWLEDGMENTS}

We thank B. Cunfer, University of Georgia, M. Palm, USDA-APHIS, and P. Paulech, Slovak Academy of Science for providing bunted seed 
samples; G. Peterson, USDA-FDWSRU for providing DNA samples from species of Tilletia; and A. Rossman and A. Tschanz for critically reviewing the manuscript.

\section{LITERATURE CITED}

1. Bonde, M. R., Nester, S. E., Khayat, A., Smilanick, J. L., Frederick, R. D., and Schaad, N. W. 1999. Comparison of effects of acidic electrolyzed water and $\mathrm{NaOCl}$ on Tilletia indica teliospore germination. Plant Dis. 83:627-632.

2. Bonde, M. R., Peterson, G. L., Schaad, N. W., and Smilanick, J. L. 1997. Karnal bunt of wheat. Plant Dis. 81:1370-1377.

3. Boyd, M. L., and Carris, L. M. 1997. Molecular relationships among varieties of the Tilletia fusca (T. bromi) complex and related species. Mycol. Res. 101:269-277.

4. Boyd, M. L., and Carris, L. M. 1998. Evidence supporting the separation of the Vulpia- and Bromus-infecting isolates in the Tilletia fusca ( $T$. bromi) complex. Mycologia 90:1031-1039.

5. Boyd, M. L., Carris, L. M., and Gray, P. M. 1998. Characterization of Tilletia goloskokovii and allied species. Mycologia 90:310-322.

6. Castlebury, L. A., and Carris, L. M. 1999. Tilletia walkeri, a new species on Lolium multiflorum and L. perenne. Mycologia 91:121-131.

7. Castlebury, L. A., Carris, L. M., and Levy, L. 1999. Nuclear large subunit rDNA and ITS phylogenies in the genus Tilletia. Page 26 in: XVI Int. Bot. Congr. Abstr. Add. St. Louis.

8. Cunfer, B. M., and Castlebury, L. A. 1999. Tilletia walkeri on annual ryegrass in wheat fields in the southeastern United States. Plant Dis. 83:685-689.

9. Durán, R. 1987. Ustilaginales of Mexico. Washington State University, Pullman.

10. Durán, R., and Fischer, G. W. 1961. The genus Tilletia. Washington State University, Pullman.

11. Frederick, R. D., Snyder, K. E., Tooley, P. W., Berthier-Schaad, Y., Peterson, G. L., Bonde, M. R., Schaad, N. W., and Knorr, D. A. 2000. Identification and differentiation of Tilletia indica and T. walkeri using PCR. Phytopathology 90:951-960.

12. Fuentes-Davila, G. 1996. Karnal bunt. Pages 26-32 in: Bunt and Smut Diseases of Wheat. Concepts and Methods of Disease Management. R.
D. Wilcoxson and E. E. Saari, eds. CIMMYT, Mexico.

13. Holton, C. S. 1949. Observations on Neovossia indica. Indian Phytopathol. 2:1-5.

14. Maniatis, T., Fritsch, E. F., and Sambrook, J. 1982. Molecular Cloning: A Laboratory Manual. Cold Spring Harbor Laboratory, Cold Spring Harbor, New York.

15. McDonald, J. G., Wong, E., Kristjansson, G. T., and White, G. P. 1999. Direct amplification by PCR of DNA from ungerminated teliospores of Tilletia species. Can. J. Plant Pathol. 21:78-80.

16. Mitra, M. 1931. A new bunt of wheat in India. Ann. Appl. Biol. 18:178179.

17. Mitra, M. 1935. Stinking smut (bunt) of wheat with special reference to Tilletia indica. Indian J. Agric. Sci. 5:1-24.

18. Pimentel, G., Carris, L. M., Levy, L., and Meyer, R. J. 1998. Genetic variability among isolates of Tilletia barclayana, T. indica and allied species based on RAPD and PCR-RFLP analysis. Mycologia 90:10171027.

19. Royer, M. H., and Rytter, J. 1988. Comparison of host ranges of Tilletia indica and T. barclayana. Plant Dis. 72:133-136.

20. Seifert, K. A., Wingfield, B. D., and Wingfield, M. J. 1995. A critique of DNA sequence analysis in the taxonomy of filamentous ascomycetes and ascomycetous anamorphs. Can. J. Bot. 73:760-767.

21. Smith, O. P., Peterson, G. L., Beck, R. J., Schaad, N. W., and Bonde, M. R. 1996. Development of a PCR-based method for identification of Tilletia indica, causal agent of Karnal bunt of wheat. Phytopathology $86: 115-122$

22. Tullis, E. C., and Johnson, A. G. 1952. Synonymy of Tilletia horrida and Neovossia barclayana. Mycologia 44:773-788.

23. Vánky, K. 1994. European Smut Fungi. Fischer Verlag, New York.

24. White, T. J., Bruns, T., Lee, S., and Taylor, J. 1990. Amplification and direct sequencing of fungal ribosomal RNA genes for phylogenetics. Pages 315-322 in: PCR Protocols: A Guide to Methods and Applications. M. A. Innis, D. H. Gelfand, J. J. Sninsky, and T. J. White, eds. Academic Press, San Diego, CA.

25. Whitney, N. G. 1989. Taxonomy of the fungus causing kernel smut of rice. Mycologia 81:468-471.

26. Ykema, R. E., Floyd, J. P., Palm, M. E., and Peterson, G. L. 1996. First report of Karnal bunt of wheat in the United States. Plant Dis. 80:1207. 